International Journal of English Literature and Social Sciences
Vol-6, Issue-1; Jan-Feb, 2021

\title{
Research on the establishment plan of industry investment fund of military-civilian integration
}

\author{
$\mathrm{Li} \mathrm{Na}$
}

Institute for Finance and Economics, Central University of Finance and Economics, Beijing, China

Received: 01 Nov 2020; Received in revised form: 29 Dec 2020; Accepted: 08 Jan 2021; Available online: 13 Jan 2021

C2021 The Author(s). Published by Infogain Publication. This is an open access article under the CC BY license

(https://creativecommons.org/licenses/by/4.0/).

\begin{abstract}
Industry investment fund of military-civilian integration is an effective financial tool to promote the deep development of military-civilian integration, which combines the strategic guiding ideology of the government and the rules of market operation. Starting from the analysis of industrial investment fund, this paper introduces the military-civilian integration industrial investment fund as a financial innovation product, then discusses the feasibility of establishing the fund from the perspective of the demand and supply of the "product", and then summarizes the suitable establishment scheme of the fund according to the operation of the existing domestic military-civilian integration industrial investment fund.
\end{abstract}

Keywords_-financial innovation; military-civilian integration; industrial investment fund.

\section{INTRODUCTION}

In the wake of the military-civilian integration rising to the height of national strategy, its industry also needs further development. In order to effectively promote its development, there is an urgent need for a scientific, standardized and open new financing platform. As an innovative financial product, military-civilian integration industrial investment fund is born. At present, although some provinces in China have set up investment funds for military-civilian integration industry, such as Shanxi, Shaanxi and Sichuan provinces, they are still in the initial stage in terms of scale, operation system and management mechanism, They are still in the process of exploration and attempt, and need further exploration combined with theory and practice. As an innovative investment and financing means to support its development, military-civilian integration industry investment fund is an urgent carrier to promote the financing mode of military-civilian integration industry. It effectively combines the strategic guiding ideology of the government with the market operation, therefore the research on it has certain practical significance.

\section{THE DEFINITION OF INDUSTRIAL INVESTMENT FUND FOR MILITARY-CIVILIAN INTEGRATION}

Fund is a kind of investment tool with collective investment and expert management. According to the liquidity of fund, it can be divided into industrial investment fund with unlisted equity as the main investment object and securities investment fund with various securities as the main investment object. Industrial 
investment funds mainly include restructuring funds, venture capital funds, infrastructure funds and other non listed equity funds. Securities investment funds mainly are consist of stock funds, bond funds and monetary funds. The similarities between the two funds lie in that both of them raise funds by issuing fund beneficiary bonds, which are operated by an investment management organization composed of experts, and diversify the fund assets to reduce risks and share profits. The main difference lies in investment motivation and liquidity. Industrial investment funds pay more attention to the increase of capital and the improvement of enterprise efficiency, with poor flexibility and relatively high risk, while securities investment funds show solicitude for to the changes of stock prices, with good liquidity and low risk. Whereas the foothold of the paper in the issue of industrial investment funds, for other types of funds here will not do a detailed introduction.

Industrial investment fund is a kind of collective investment system, which shares the benefits and risks of unlisted enterprises and provides management services. For enterprises engaged in industrial investment, it is an innovative financial system, which can help enterprises enrich their real capital and form tangible or intangible assets, such as machinery and equipment, factories, raw materials, proprietary technology, patents and so on. It can invest in all kind of industries. At the moment, strategic emerging industries, culture and high-tech industry investment funds are more common in China. Military-civilian integration industry usually refers to those economic activities that make the production of military products and civil products penetrate and cross each other, and finally realize the open sharing and rational allocation of military and civilian resources, as well as the mutual transfer of dual-use technologies. It is driven by solving the problem of repeated investment between national defense expenditure and national economic input, mainly including aerospace, shipbuilding, modern vehicles, optoelectronic information, new materials, new energy, energy conservation and environmental protection, high-end equipment manufacturing, security products, satellite communications and other industries. The industrial investment fund of military-civilian integration is a new collective investment and financing system, which provides financial capital support for unlisted enterprises participating in military-civilian integration activities, and promotes the transformation of government behavior into market behavior under the principles of coordination, openness and standardization.

\section{A FEASIBILITY STUDY ON THE}

\section{ESTABLISHMENT OF INDUSTRIAL INVESTMENT} FUND FOR MILITARY-CIVILIAN INTEGRATION

In order to find out the feasibility of establishing the industrial investment fund for military-civilian integration, we can regard the industrial investment fund as a new type of "product" in a sense. However, any kind of innovation will inevitably face some obstacles and risks at the beginning, and the military-civilian integration industrial investment fund is no exception. Although we will face obstacles and risks, from the perspective of "product" demand and supply, there are not only corresponding suppliers willing to invest in production, but also corresponding demanders willing to accept. The following will analyze the feasibility of establishing the fund from the demand and supply of the military-civilian integration industry fund.

\section{1"Demand side" of industrial investment fund for military-civilian integration}

For the demand source of this product, we can consider from three aspects: the limited scale of government funds at the macro level, the growth of military-civilian integration industry at the meso level and the development of military-civilian integration related enterprises at the micro level.

From a macro perspective, military enterprises controlled by the government have been experiencing the problem of single financing means. They mainly rely on state investment, and the degree of financial support is mainly determined by the decision-making group, national development strategy and security environment. However, at present, the total amount of financial funds is limited, and the balance of central financial debt is increasing year by year. Therefore, relying only on government funds to support the development of military enterprises is facing great restrictions. In addition, the financing mode relying on government investment has a series of problems, such as inefficient use of funds, imperfect supervision system 
and low return on investment. Therefore, in the process of promoting the development of military-civilian integration industry, the government needs to innovate its support methods. If we blindly take the way of direct subsidy or direct investment, we will not be able to achieve the ultimate goal. Therefore, from the perspective of the government's coordinated development of national defense and economic construction, it is urgent to mobilize all useful forces to promote the development of military-civilian integration industry. Thus it has become a demand of the government to adhere to the diversified market financing and actively innovate the investment and financing mechanism.

From the medium level, the current stage of industrial life cycle of military-civilian integration industry determines that it needs the support of industrial investment fund. Generally speaking, the industry life cycle can be divided into four stages: start-up stage (introduction stage), growth stage, mature stage and decline stage ${ }^{1}$.

Table. 1 different characteristics of industry in four stages of life cycle

\begin{tabular}{|c|c|c|c|c|}
\hline Project & Initial stage & Growth stage & Mature stage & Recession stage \\
\hline Product category & $\begin{array}{c}\text { Single product, no } \\
\text { obvious advantages, } \\
\text { high product cost }\end{array}$ & $\begin{array}{l}\text { The products are } \\
\text { developing in the } \\
\text { direction of } \\
\text { diversification /high } \\
\text { quality, and the } \\
\text { product cost is } \\
\text { decreasing }\end{array}$ & $\begin{array}{c}\text { Increased } \\
\text { production and } \\
\text { standardized } \\
\text { production of } \\
\text { products }\end{array}$ & $\begin{array}{c}\text { Products are aging and } \\
\text { substitutes appear } \\
\text { frequently }\end{array}$ \\
\hline Industrial scale & $\begin{array}{l}\text { The number and } \\
\text { scale of enterprises } \\
\text { are small, but the } \\
\text { growth rate is } \\
\text { significant }\end{array}$ & $\begin{array}{l}\text { The number of } \\
\text { enterprises has } \\
\text { greatly increased and } \\
\text { the scale has } \\
\text { gradually expanded }\end{array}$ & $\begin{array}{l}\text { It has a relatively } \\
\text { stable scale and } \\
\text { forms a complete } \\
\text { industrial chain }\end{array}$ & The scale is shrinking \\
\hline $\begin{array}{c}\text { Market } \\
\text { conditions }\end{array}$ & $\begin{array}{l}\text { The product price is } \\
\text { high, the market } \\
\text { share is low and the } \\
\text { market risk is high }\end{array}$ & $\begin{array}{c}\text { The market } \\
\text { environment is clear } \\
\text { and there are } \\
\text { relatively systematic } \\
\text { industrial support } \\
\text { policies }\end{array}$ & $\begin{array}{c}\text { Mature market and } \\
\text { orderly market } \\
\text { competition }\end{array}$ & Shrinking market share \\
\hline Market demand & $\begin{array}{l}\text { Market demand } \\
\text { exists, but space is } \\
\text { limited }\end{array}$ & $\begin{array}{l}\text { The market demand } \\
\text { expands and the } \\
\text { growth rate rises }\end{array}$ & $\begin{array}{c}\text { The market demand } \\
\text { is stable and } \\
\text { increasingly } \\
\text { saturated }\end{array}$ & $\begin{array}{c}\text { Shrinking market } \\
\text { demand }\end{array}$ \\
\hline Income level & Loss or small profit & Profit increase & $\begin{array}{c}\text { The profits are } \\
\text { stable and reach a } \\
\text { high level }\end{array}$ & Lower profits \\
\hline Technical status & $\begin{array}{l}\text { Technology research } \\
\text { and development has } \\
\text { achieved certain } \\
\text { results, but the cost is } \\
\text { high }\end{array}$ & $\begin{array}{l}\text { Various technical } \\
\text { systems of product } \\
\text { process have been } \\
\text { completed }\end{array}$ & $\begin{array}{l}\text { Mature technical } \\
\text { conditions and } \\
\text { effective connection } \\
\text { with upstream and } \\
\text { downstream }\end{array}$ & $\begin{array}{c}\text { Stagnation of } \\
\text { technology research } \\
\text { and development }\end{array}$ \\
\hline
\end{tabular}


industries

Product innovation

\begin{tabular}{|c|c|c|c|c|}
\hline Innovation mode & $\begin{array}{c}\text { Active product } \\
\text { innovation }\end{array}$ & $\begin{array}{c}\text { keeps pace with } \\
\text { industrial } \\
\text { development }\end{array}$ & $\begin{array}{l}\text { Less product } \\
\text { innovation }\end{array}$ & Innovation stops \\
\hline
\end{tabular}

According to the characteristics of the four stages, it can be concluded that military-civilian integration industry in China has just transited from the initial stage to the growth stage. The industry in this stage is diversified and the quality is improved. The expansion of market demand space and the scale of enterprises, the increase of mortgage assets and the improvement of credit and other factors have been able to get rid of the limitation of only relying on internal financing to a certain extent, and then turn to external financing. Therefore, in addition to commercial bank credit, bond financing and equity financing, the industrial investment fund set up by the government to support related industries is also a good choice. The military-civilian integration industrial investment fund came into being.

The life cycle stage of military-civilian integration industry determines that its development is inseparable from the participation of industrial investment funds. In addition, another reason for the demand is the dynamic characteristics of its growth. One of the key driving forces for the growth of military-civilian integration industry is "innovation", and industrial investment fund can provide a certain driving force for the growth of military-civilian integration industry. There are three ways to achieve it. First is to cultivate new technology and creativity. One of the signs of the growth of military-civilian integration industry is the integration of high-tech and industrial content. The invention of high-tech and the acquisition of valuable ideas are inseparable from a large amount of capital investment. Second is to cultivate and restructure new military-civilian integration enterprises. Another sign of the growth of military-civilian integration industry is the internal integration and reorganization of military-civilian integration industry. The addition of industrial investment fund can provide new enterprises with hardware elements such as capital and labor, and software elements such as technology, information and entrepreneur ability. Only with the supply of these elements can these new reorganized enterprises develop gradually. The third is to speed up the renewal of innovation system. In the growth of military-civilian integration industry, the role of system is very significant. Industrial investment funds can gather a large number of resources in a short period of time, and use these resources in innovation activities. With the cooperation of relevant policies, the evolution of innovation system can be accelerated to a certain extent. 


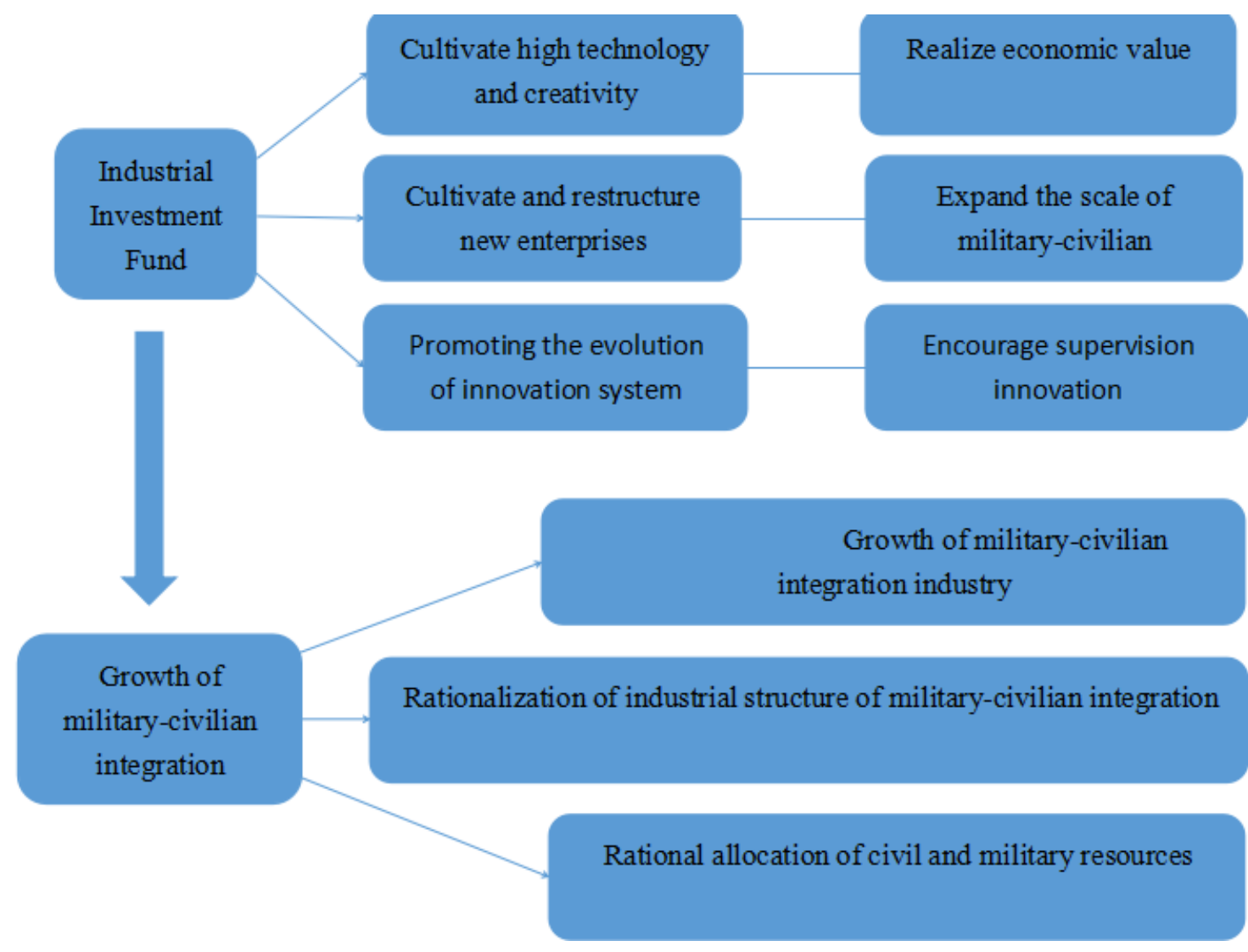

Fig. 1 The path of industrial investment fund supporting the development of military-civilian integration industry

From the micro level, in order to pursue their own development, the military-civilian integration related enterprises have a certain demand for the "product". For those enterprises with insufficient funds, the military-civilian integration industry investment fund will bring them the following two aspects of convenience. In order to obtain these conveniences, they naturally have a certain demand for the industrial investment funds of military-civilian integration.

First, the investment fund of military-civilian integration industry is a new investment and financing mechanism, which is conducive to increasing the proportion of direct financing of military-civilian integration enterprises and reducing the debt ratio of enterprises. It can provide financial support in the R\&D stage of enterprises, alleviate the problem of insufficient investment in innovation activities of military-civilian integration enterprises, shorten the time of technological breakthrough and commercialization, so as to help enterprises enhance their intrinsic value and obtain listing qualification.

Second, there is often the problem of information asymmetry between military-civilian integration enterprises and investors. Military-civilian integration industrial investment fund can build a bridge between enterprises and investors, enhance communication and coordination and investor relations, and alleviate the problem of information asymmetry between them. 


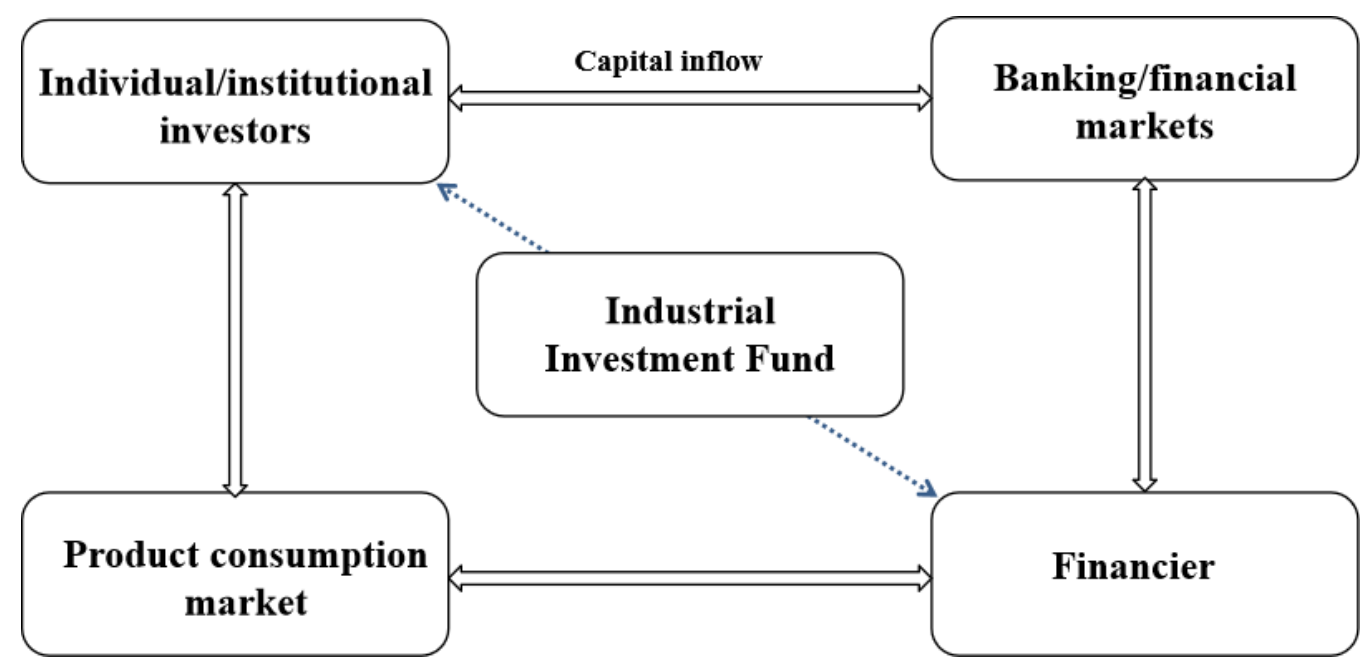

Fig. 2 Industrial investment fund structure investment and financing mode chart

\subsection{The "supplier" of industrial investment fund for military-civilian integration}

The capital sources of industrial investment funds mainly include government financial funds, financial institutions and social capital. Because the industrial investment fund of military-civilian integration belongs to the category of industrial investment fund, its "supplier" is more likely to come from the above funds. Next, we will analyze the reasons why these funds are willing to act as the supplier of the "product". The reason why the government financial funds are willing to be the "supplier" of the industrial investment fund is mainly due to the following considerations. Military-civilian integration is a national strategy integrating national defense construction and economic construction, and promoting its development is a measure beneficial to the country and the people. The development of military-civilian integration industry is conducive to the realization of military-civilian integration, two-way transformation, mutual promotion and coordinated development within the industry. The achievements of military-civilian integration industry can provide support for national defense construction and building a world-class army. The innovation and achievement transformation of dual-use technology can cultivate new kinetic energy and promote high-quality economic development. Therefore, to promote its development, the government has an unshirkable responsibility and needs to plan from the national level. On the one hand, it improves the strength of the national finance to leverage social capital, effectively alleviates the pressure of the lack of financial funds; on the other hand, it can realize the function of the finance to rationally allocate resources and adjust the economy by using a variety of means. Therefore, from the perspective of the government, as the "supplier" of the fund, why not.

In addition to the supply side of financial funds, the other big supplier comes from the capital of financial institutions. In recent years, the scale of social financing in China has expanded year by year. The so-called social financing refers to the financing obtained by the real economy from the financial system, and its scale growth rate is more than $10 \%$ year-on-year, and even as high as $34 \%$ in some years. It can be seen that the financial system has strong desire to invest in the real economy. As a promising real economy, military-civilian integration industry is bound to become one of the key investment targets in the financial system.

Futhermore, in addition to the government financial funds and financial institutions willing to be the "supplier" of the fund, under the guidance of government funds, some idle social funds such as individuals and social institutions also have the intention to participate in the fund. The reason why these funds are willing to serve as "suppliers" mainly comes down to the following considerations. First, because the financial funds participate in the establishment of the industrial investment fund, the invested enterprises have relatively high credibility, so the profit seeking social capital is willing to invest in such enterprises. Second, the 
current military-civilian integration industry is developing well with the support of national policies. For the enterprises that invest in it, they can cultivate new profit growth points for their enterprises, improve their comprehensive competitiveness and industry influence, and then achieve sustainable, healthy and stable development.

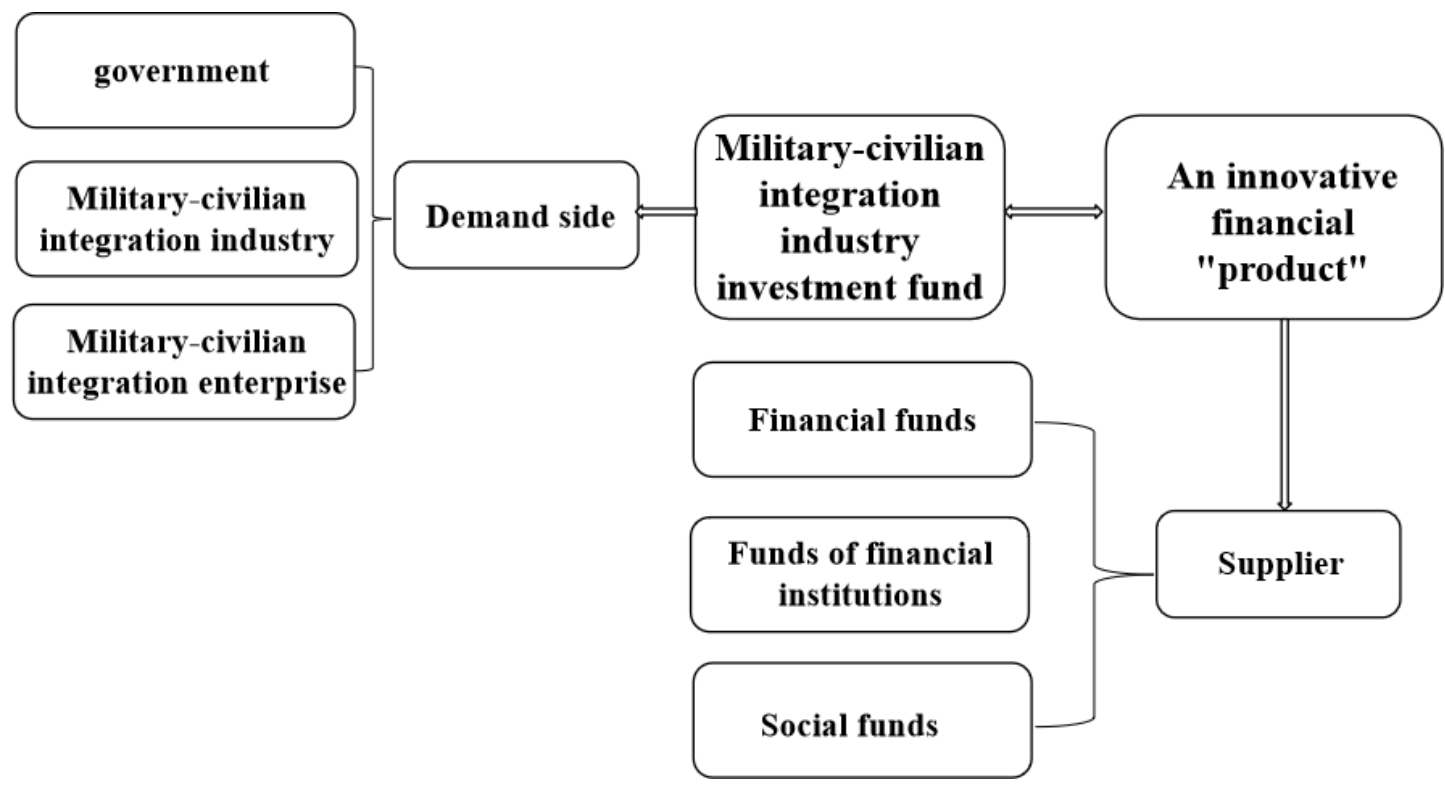

Fig. 3 Structure chart of supply and demand sides of military-civilian integration industry investment fund

IV. THE CONSTRUCTION OF INDUSTRIAL

\section{INVESTMENT FUND FOR MILITARY-CIVILIAN INTEGRATION}

Any kind of industrial investment fund should be designed for its operation at the beginning of its establishment, and military-civilian integration industrial investment fund is no exception. The following will be combined with the current operation of the military-civilian integration industry investment fund and the relevant theory of industrial investment fund establishment, respectively from the establishment of military-civilian integration industry investment fund organization mode, operation mode (including financing mode, investment mode, exit mode) and management mode, to design a set of effective operation method for military-civilian integration industry investment fund case.

Table. 2 The current situation of investment funds for military-civilian integration industry in China

\begin{tabular}{|c|c|c|c|c|}
\hline Time & Site & Scale & Sponsor & Organization mode \\
\hline 2017 & $\begin{array}{l}\text { Xi'an high -tech } \\
\text { Zone }\end{array}$ & 10 billion & Xi'an high -tech Zone & Limited partnership \\
\hline 2017.9 & Shanghai & $\begin{array}{l}\text { The scale of the } \\
\text { first phase is } 4 \\
\text { billion }\end{array}$ & $\begin{array}{l}\text { Guosheng group takes the lead in } \\
\text { operation and } 11 \text { units contribute }\end{array}$ & Limited partnership \\
\hline 2017.10 & Henan Province & 50 billion & $\begin{array}{c}\text { Henan investment group, } \\
\text { Zhongyuan Yuzi investment } \\
\text { holding group and Luoyang City }\end{array}$ & Limited partnership \\
\hline 2018.3 & $\begin{array}{c}\text { Qingdao West } \\
\text { Coast New Area }\end{array}$ & 10 billion & $\begin{array}{l}\text { Qingdao civil Military Integration } \\
\text { Development Group Co., Ltd., } \\
\text { Qingdao West Coast New Area }\end{array}$ & Limited partnership \\
\hline
\end{tabular}




\begin{tabular}{|c|c|c|}
\hline 2018.4 & Xi'an, Shaanxi & Unknown \\
\hline & Chengdu high & \\
\hline 2018.4 & $\begin{array}{l}\text {-tech Zone, } \\
\text { Sichuan }\end{array}$ & Over 5 billion \\
\hline 2018.4 & $\begin{array}{l}\text { Foshan, } \\
\text { Guangdong }\end{array}$ & $\begin{array}{l}10 \text { billion (the } \\
\text { first phase is } 1 \\
\text { billion yuan) }\end{array}$ \\
\hline
\end{tabular}

\subsection{The organization of industrial investment fund for military-civilian integration}

At present, industrial investment fund can choose corporate fund, trust fund and limited partnership fund.

The corporate fund makes extensive investment by issuing fund shares to raise funds. The ownership of the assets of the fund company belongs to the investors (shareholders). The shareholders elect the board of directors according to the procedure, and the board of directors selects the fund management company, which is responsible for managing the fund business. In the contract system, a trust investment contract is usually signed by the fund manager, the fund trustee and the fund investor. The fund manager is the initiator of the fund, who raises funds by issuing beneficiary certificates to form trust property, invests according to the trust contract, and undertakes the corresponding trustee responsibilities. The fund trustee shall be responsible for the custody of the trust property in accordance with the trust contract. The fund investors share the investment results according to the trust contract. Investors of limited partnership funds participate in investment as partners and enjoy the property rights of the partnership according to law. There are usually two types of partners: general partners and limited partners. The general partner is usually a senior fund manager, who is responsible for managing the investment of the partnership and bearing unlimited liability for the debts of the partnership, thus closely connecting the responsibility of private enterprise joint

investment group Co., Ltd

Northwest University of

Technology (capital of China

University of Technology) and

Limited partnership

Lingqing Investment Group

Chengdu hi tech Zone will invest

1 billion yuan to set up a master

fund and absorb social capital,

with a total scale of no less than 5

Limited partnership

(tentative)

billion yuan

Foshan City and Shunde District

will jointly guide and launch
Unknown the fund manager with the investment benefit of the fund. Limited partners are mainly institutional investors, the main providers of investment funds, and do not participate in the daily management of the partnership. In December 2016, the national development and Reform Commission issued "the Interim Measures for the management of government funded industrial investment funds", which mentioned that government funded industrial investment funds should also adopt these three organizational modes.

As a kind of government funded and guided fund, military-civilian integration industry investment fund can be used in the operation of the three kinds of organization forms in theory. However, there are some differences in the rights of investors, tax status, fund raising, capital withdrawal and supervision mechanism.

Based on the above comparative analysis, the author believes that limited partnership fund has its own advantages in investor rights, tax status, fund raising and withdrawal, and supervision mechanism. In this way, the government can participate as a limited partner in the investment fund of military-civilian integration industry. For one hand, it can play the guiding role of the government, For another, it can avoid the government's direct intervention in the daily management of the fund, and ensure that the fund operates according to the market rules. To a certain extent, this can alleviate the contradiction between the interest demands of the government and the profit seeking social capital. Limited 
partnership is a common form of industrial investment fund in China, and most of the existing military-civilian integration industrial investment funds also use this form, such as Sichuan military-civilian integration industrial investment fund. In view of the above analysis, the author thinks that the limited partnership is suitable for the operation of the industrial investment fund of military-civilian integration in China.

\subsection{The operation mode of industrial investment fund for military-civilian integration}

The operation mode of military-civilian integration industry investment fund mainly involves three aspects: financing mode, investment mode and exit mode. The following three aspects will be discussed.

4.2.1 The financing mode of industrial investment fund for military-civilian integration

From the analysis of the "supply and demand side" of the industrial investment fund, we can see that there are government departments, financial institutions and social institutions contributing to the fund. As mentioned above, military-civilian integration industry of China is in the transition stage from the initial stage to the growth stage, and shows the characteristics of high risk, high investment and non-standard. Therefore, the low willingness of profit seeking social capital to intervene in the industry determines that the financing mode of the industry needs the government to establish a preliminary framework, and initiate the establishment of the industry investment fund by combining public offering and private offering. In the process of raising funds, the government should play the role of a good guide, play a guiding role, attract social capital to participate, maximize the leverage of finance, and achieve the purpose of "small" prying "big".

4.2.2 The investment mode of the industrial investment fund of military-civilian integration

The industry of military-civilian integration can be divided into two directions: "military to civilian" and "civilian to military", so its investment mode is also aimed at the two directions. Specifically, we can invest in the following four directions: (1)The high-tech industry of military-civilian integration formed by the transfer and transformation of military technology and the development of dual-use technology includes aerospace, aviation, shipping, nuclear energy, space information, dual-use electronic information, dual-use intelligent equipment, dual-use new materials and so on. (2)High-tech enterprises participating in the scientific research and production of weapons and equipment, and related civilian enterprises with strong innovation vitality but insufficient financing capacity. (3)Military industrial enterprises with specialized restructuring (joint stock reform, reform of military scientific research institutes, etc.). (4)In line with the government's development strategy, the construction of core carriers such as military-civilian integration industrial base, industrial park, technology platform, etc.

4.2.3 Exit mode of industrial investment fund for military-civilian integration

There are three exit mechanisms of industrial investment funds. The first is that the invested enterprise transfers its shares through the stock market after it is listed, so as to withdraw from the invested enterprise. The second is through the transfer of the unlisted shares of the invested enterprise, which can be external transfer or internal transfer. The third is that the invested enterprise fails to operate and withdraws from the invested enterprise through bankruptcy liquidation procedure. At present, the three exit mechanisms are also applicable to the investment fund of military-civilian integration industry. The specific form of exit mechanism should be based on the operation of the invested enterprises. Up to now, the established military-civilian integration industry investment funds in China are still in existence, and have not yet reached the stage of exit.

However, no matter which exit method is chosen, the particularity of military-civilian integration industry should be fully considered. In order to ensure the security of the national strategic industry of military-civilian integration, the government can be given corresponding rights when withdrawing, such as preventing foreign institutions from taking over the company maliciously and opposing any company transaction or shareholding that threatens national defense and security. The government can limit the scope of investors to a certain extent to ensure a safe exit. 


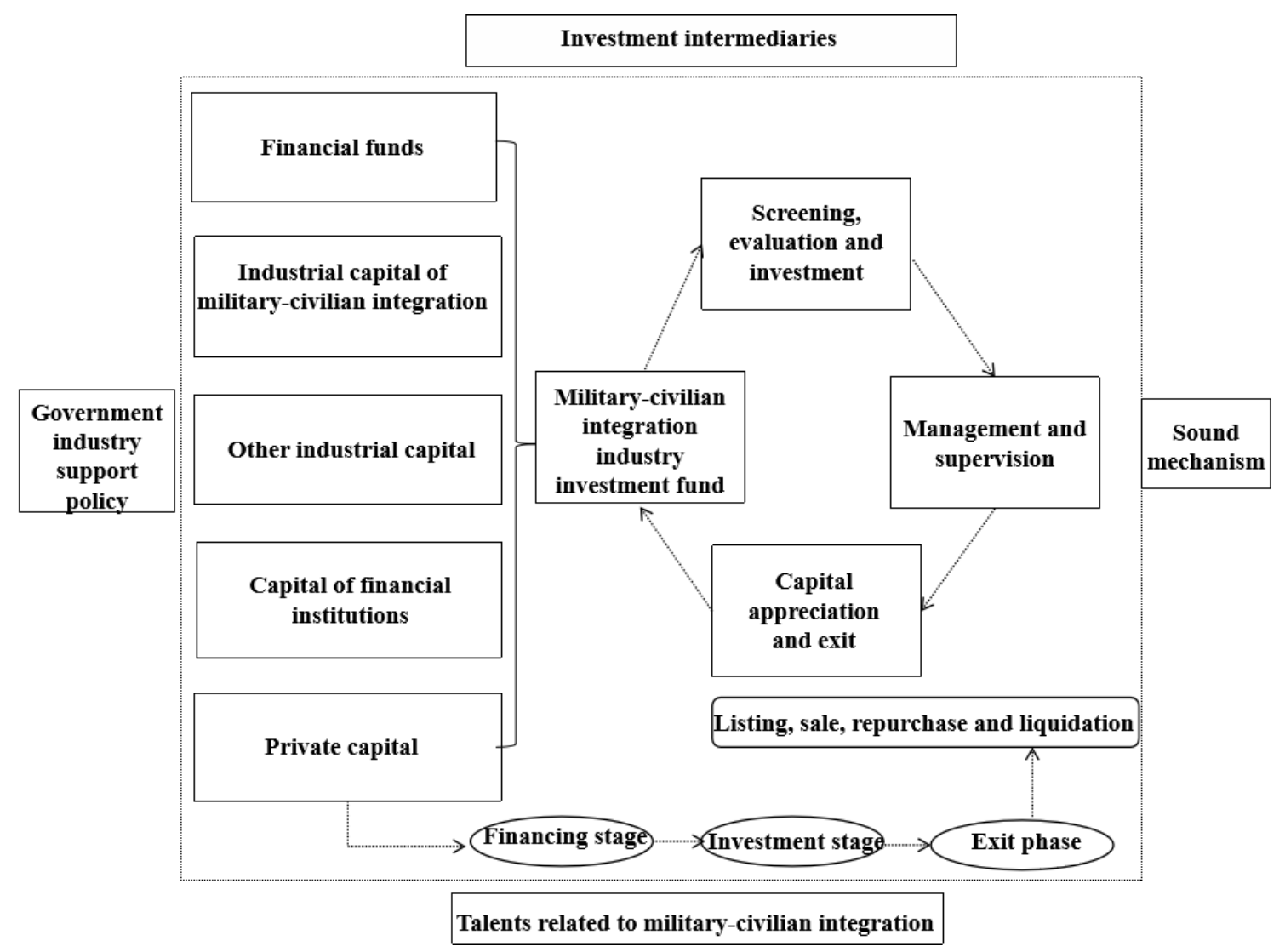

Fig. 4 Operation system of industrial investment fund for military-civilian integration

\subsection{Management mode of industrial investment fund for military-civilian integration}

At present, industrial investment funds can adopt two management modes: self-management mode and entrusted management mode. The self-management type means that the fund company manages the assets of industrial investment fund and implements the investment operation business by itself, and implements the authorized operation mechanism within the company. This kind of management mode has some advantages, but also has some limitations. The advantages are mainly manifested in two aspects. Firstly, this mode does not need to seek the help of other management companies, so it saves a sum of money and trivial matters in capital management. On the other hand, it can make the corresponding personnel of the company better understand the investment and management of funds. The limitation is that this mode may lead to the damage of the company due to the ability problems of the relevant personnel of fund management. Entrusted management is a kind of principal-agent mode that entrusts a relatively independent professional investment institution to be responsible for the investment, operation and management of fund assets. The purpose is to ensure the institutionalization and specialization of the management team.

In view of the choice of the two management modes, we should choose the appropriate institutional arrangement according to the external environment of the military-civilian integration industrial investment fund in the actual operation. At present, the investment fund of military-civilian integration industry in China is still in the initial stage, and the corresponding market incentive mechanism and restraint mechanism are not perfect. In order to satisfy the board's desire to participate in the fund's major decision-making, so as to achieve the purpose of attracting investors, we can first use the self-management model. With the gradual improvement of the corresponding mechanism, when we have the conditions to pursue the institutionalization and specialization of investment management, we can choose 
the principal-agent model. However, in view of the particularity of the military-civilian integration industry, we should strengthen the supervision of the management organization to ensure the core technology and national strategic security when choosing the principal-agent management mode.

\section{CONCLUSIONS}

Military-civilian integration industry investment fund plays an important role in military-civilian integration industry. Its important position is not only reflected in the total scale of funds, but also in the quality of funds. Through the research on the industrial investment fund of military-civilian integration, this paper draws the following conclusions.

First, the investment fund of military-civilian integration industry is an innovative investment and financing mechanism for military-civilian integration related industries.

Second, as an innovative financial "product", the military-civilian integration industrial investment fund has its own unique demand side and supply side. From the perspective of product supply and demand theory, it has a certain rationality.

Third, there are some similarities between the military-civilian integration industrial investment fund and other industrial investment funds in terms of organizational form, operation mode and management mode. However, due to the particularity of military-civilian integration industry and its current development in China, there are some differences in the choice of investment funds with other industries.

\section{REFERENCES}

[1] R.vernon. International investment and international trade in the product cycle $[\mathrm{J}]$. Quarterly Journal of Economics, 1966, 80(2): 190-207.

[2] Ding Deke. Government promotion: an effective way to accelerate the construction of military-civilian integration industrial base[J]. National Defense Science and Technology Industry, 2011(03): 30-33.

[3] Fan Yixia, Sun Jiaxi. Practice and improvement of local government guiding fund operation $[\mathrm{J}]$. Research on Local Finance, 2016(11): 96-100.

[4] Gan Chunhui, Zheng Ruogu and Yu Fanfan. The impact of China's industrial structure change on economic growth and fluctuation[J]. Economic Research, 2011, 46(05): 4-16+31.

[5] Gong Cheng, Li Yunda. The development opportunity of industrial investment fund and the intervention path of commercial banks[J]. International Finance, 2015(12): 25-30.

[6] $\mathrm{Hu}$ Dongliang. Research on the financing of military-civilian integration industry in China[D]. Dongbei University of Finance and Economics, 2016.

[7] Ji Minbo, Xu Lifang. Development strategy and mode selection of industrial investment fund in China[J]. Financial Research, 2000(05): 37-42.

[8] Jing Jing, Gao Ya Ni and Dong di. Research on the choice of private capital investment in China[J]. Economic Research Reference, 2018(38): 73-79.

[9] Li Sumei. Research on the comprehensive performance and development strategy of industrial investment funds in China[D]. Tianjin University of Finance and Economics, 2007.

[10] Lin Ying, Zeng Li, fan Yibin, ect. Research on support system innovation of military-civilian integration development fund[J]. Scientific and Technological Progress and Countermeasures, 2017, 34(23): 126-132.

[11] Tang Wenxian. How to define and classify military-civilian industry[J]. National Defense Science, Technology and Industry, 2014 (07): 42-43.

[12] $\mathrm{Yu}$ Lu. Process and risk management of industrial investment fund $[\mathrm{J}]$. Human resource management, 2016 (03): 158-159.

[13] Wen Laicheng. Optimize government investment guidance fund to promote sustained and healthy economic development[J]. China Finance, 2016(06): 14-16.

[14] Zhang Yang, Shao Mingji, Li Heng, ect. Analysis on the current situation of military-civilian integration fund in China[J]. Value Engineering, 2018, 37(05): 41-42.

[15] Zheng Liansheng, Zhu He, Zhong Zhen. Foreign government industry guidance fund: characteristics, mode and Enlightenment[J]. Local Finance Research, 2017(03): 30-36. 